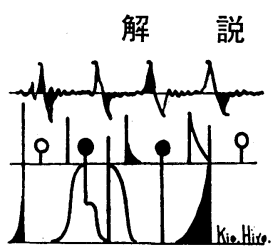

1. は じめに

建設機成の種類は非常に多いが，そのうちの土工機械 (ブルドーザ・パワーショベルなど)が土工(土の加工)を 行らとき，ほとんどすべての土工作業に共通ししかも基 本的な現象として,土の切削が行われている(図 1).土工 機械にかかる力の主要部分はこの切削抵抗であると考兄 られ，その低減ないしは合理的な土工方法の開発が望ま れるが，土を被加工物と見なす取扱いが，従来ほとんど 行われていない，そこで，土を被加工物と考光，その切 削機構を解明するための実験を行った。実験に用いた土 は, 主に乾燥した珪砂 (平均粒径 $0.2 \mathrm{~mm}$ 含水比 $0.2 \%$ ) および軟かいローム(砂粒を含んだ粘土, 含水比 32.9 $34.7 \%$, 手ざわりは粘土細工にちょうどよい程度の軟か さ) (以下 “ローム”と略す)の 2 種類である。
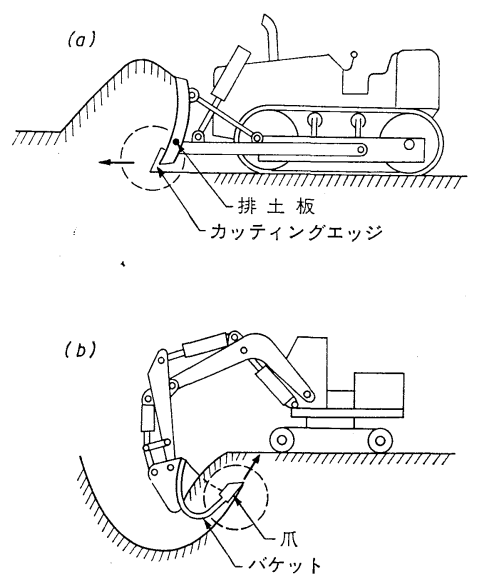

図 1 土工機娀とその土工装置.

(a) ブルドーザ
(b) パワーショベル

このうち, ロームの切削実験の結果は, 軟かい金属 (アルミニウム, 銅, 黄銅拈よび $1000^{\circ} \mathrm{C}$ 前後の軟鋼な ぞ)の切削とほとんぞ同じ傾向になっていることがわ かった，その原因を知るため，土について金属と同様の 力学的(機戍的)性質を調べたところ, 温度の影響を無視

* 東京大学助教授; 工学部産業機械工学科 1974 年 10 月 15 日受理
畑村 洋太郎*

すれば，両者は非常によく似た性質を持っていることが 明らかになった。

そこで本文では，軟かいロームをとりあげ，はじめに 土の切削機構を明らかにするための実験の概要を述べた のち，切削に関与する土の性質について金属の性質と対 比させながら説明し，最後に土(ローム)拉よ゙プラスチ シンなどを金属のシミュレータとして用いるときの問題 点について記し，読者の参考に供したい.

\section{2. 土の切削機構}

(1) 土の切削パターン(1)

砂や粘土など種々の土の切削パターンを調べたとこ ろ, 金属と同様に，せ九断形・流れ形・裂断形の三つが あることがわかった(写真 1 )。

\section{(2) 土の切削実験(2) (3)}

土の切削によって生じる変形や力学的諸量(刃物にか かる力, 刃物の表面にかかる応力の分布, 土の内部の応 力分布など)を求めるため, 図 2 に示す実験装置を用い, 2 次元切削を行った. 以下, ロームについて, 実験結果 の主なものを示す.

(3) 切削による変形

たとえば，写真 1 でもわかるとおり，ロームは流れ形 で切れており，軟かい金属とよく似ている。またこの図 から, せん断域はせん断が, 刃先前下方は引張りが動い ていることが推測されるが，このことは(6)で実証され る.

\section{(4) 切削抵抗}

たとえば切削角度を変えたときの刃物にかかる力の大 きさ，方向・着力点などは，図3のようになる。これも 軟かい金属の切削とほとんど同じ傾向を示している。

\section{（5）刃物にかかる応力の分布}

刃物表面に小形圧力計 (図 4 ) と小形摩擦力計 (図 5 ) と を埋め込んで測定した(4).

圧力 $p$ 摩擦・応力 $f$ および合応力などの分布の例を 図6に示寸。この例では $p, f$ と灭物全面にわたって

$\dagger$ 単位体積中の水の重量と土粒子の重量との比. 


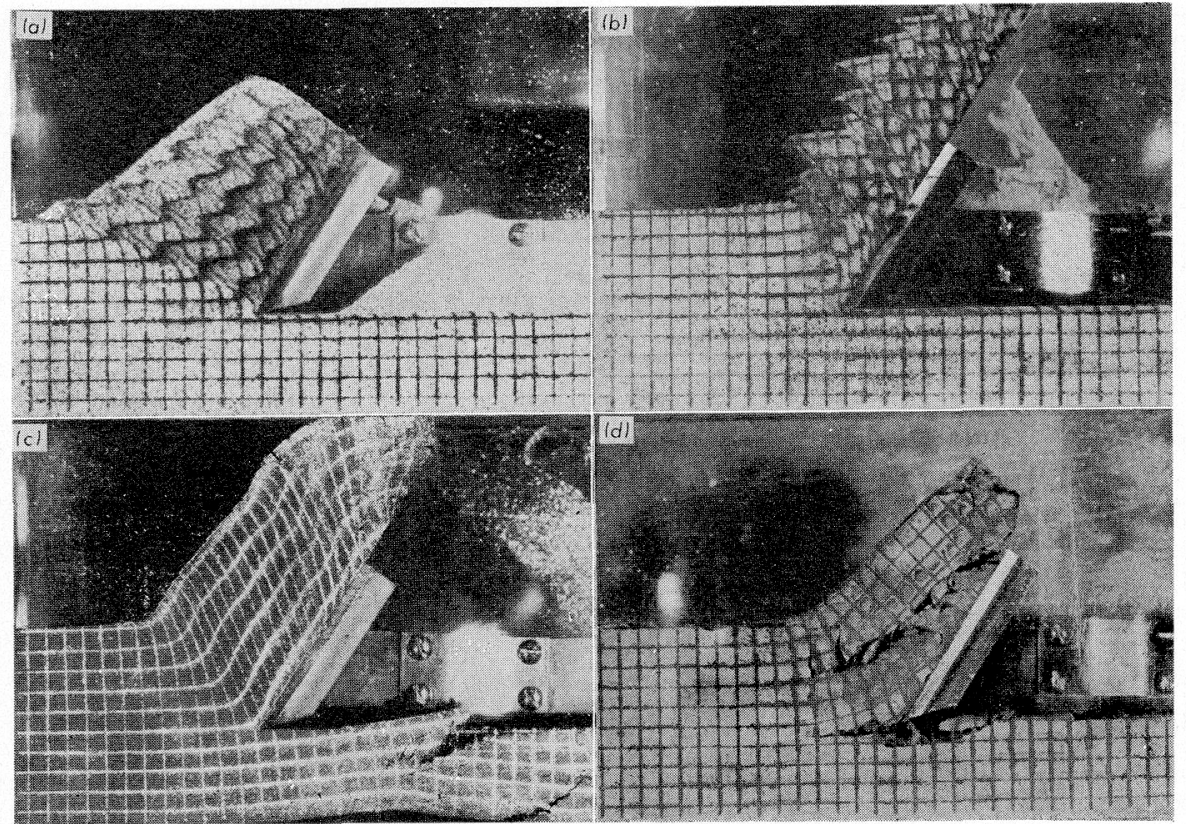

写真 1 切削による土の変形(切削パターン)。

(a) 乾燥した珪砂 (せん断形)，(b) 靯かいベントナイト(せん断形)，(c) 軟かい関東ロー 公(流れ形)，(d) 締め固めた関東口ーム(裂断形)

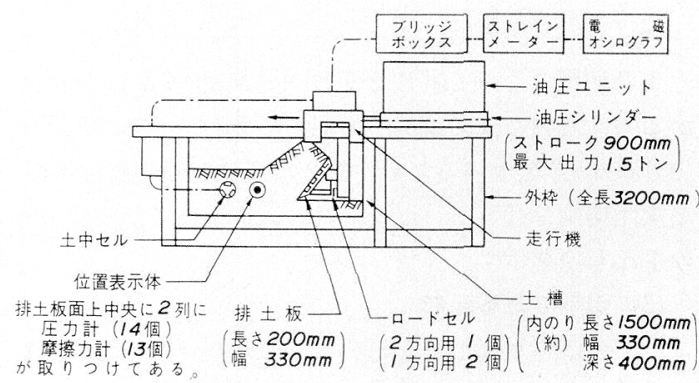

図 2 土の切削の実験装置の概要。

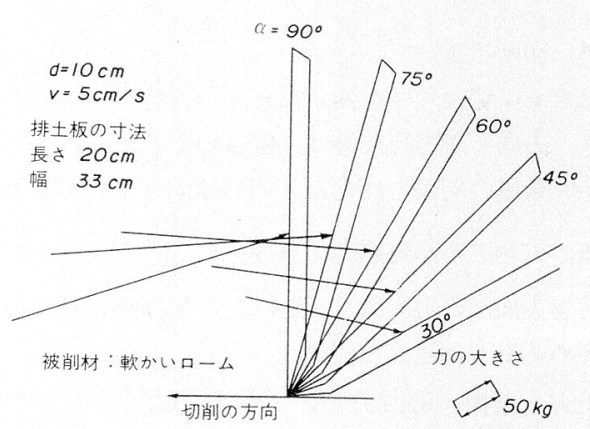

図 3 軟かい口ームの切削抵抗。

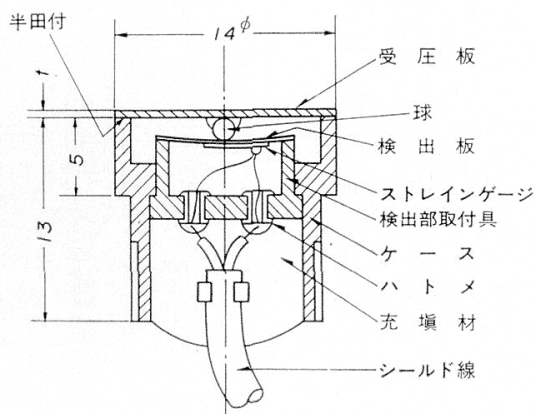

図 4 小形王力計。

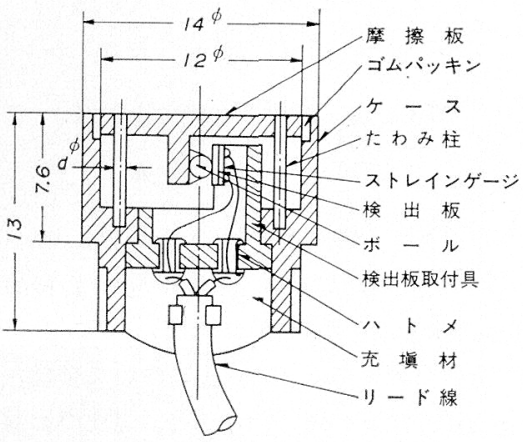

図5小形摩擦力計。 


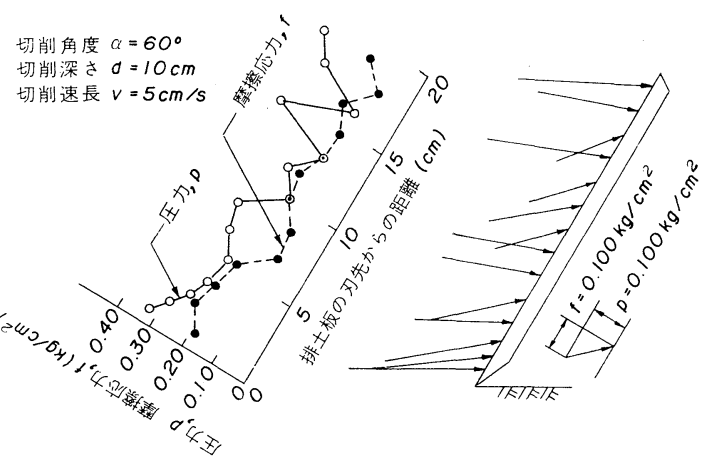

(a) 圧力・摩擦応力の分布

(b) 合応力の分布

図 6 刃物にかかる応力の分布. 被削材：軟かいローム
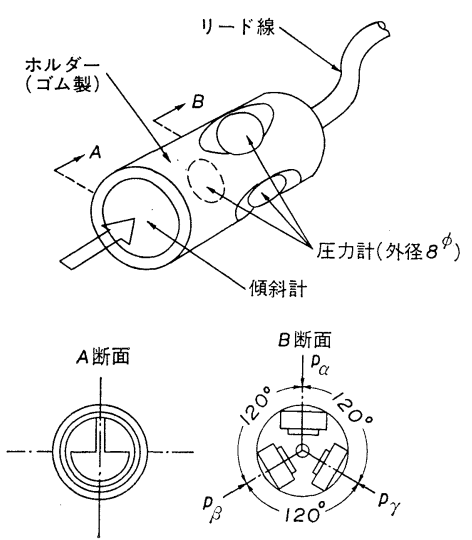

図7 小形土中セル.

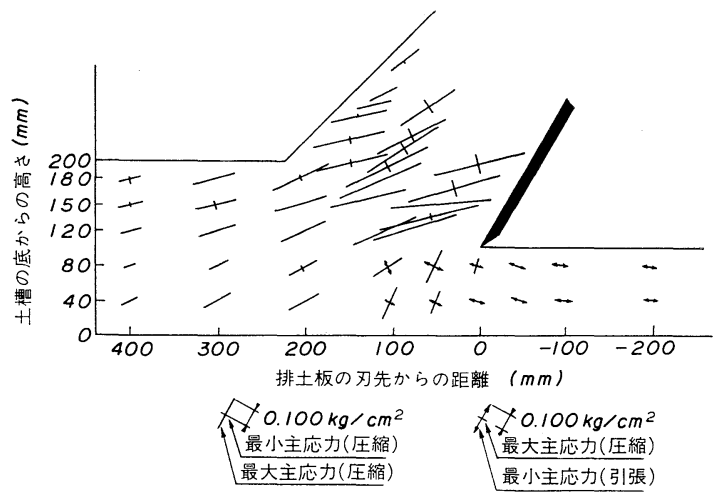

図 8 軟かいロームの切削によって生じる土の内部 の主応力分布。

ほぼ一様な分布をしている. 切削条件を変えたとき，pの 平均値は変化するが， $f$ の平均値は変化しない，従って ロームの切削では, 刃物表面と切屑との間では摩擦応力 が一定であることがわかる。このことは金属でもある程 度知られていることである。

(6) 土の内部の応力分布

土中セル (図 $7^{(4)}$ )を土の内部に埋め込み, 切削によっ て生じる土の内部の主応力の方向と大きさとを測定し
た。測定例を図 8 に示す。为物表面から発した最大主応 力線 (圧縮) は刃物からほぼ平行に発するが, 刃先から発 したものの文は急激に発散している。无告下方には引 張り応力を生じている部分がある。これらは金属では全 く測られていないことであるが，変形からある程度推測 されてはいる。な拈，このよらに内部応力を直接に測定 できることが，土の切削の大きな特徴である。

\section{（7）土の切削実験のまとめ}

以上の実䥐結果をまとめたものを図 9 に示す。
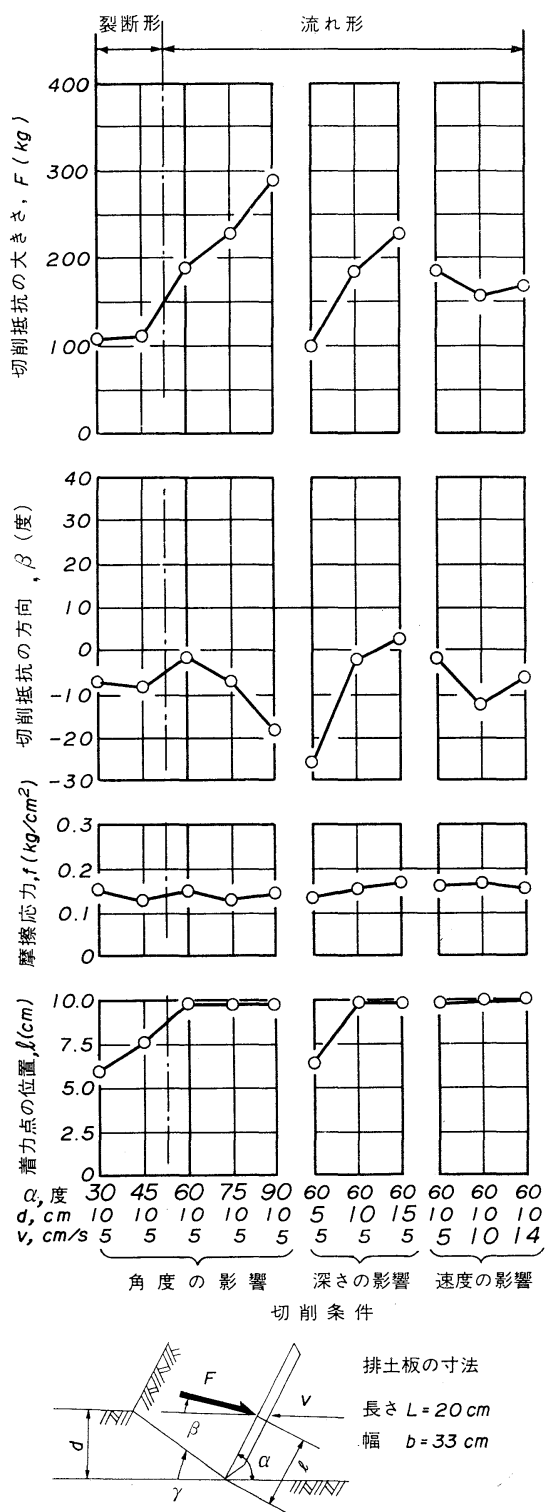

図 9 軟かい口-ムの切削抵抗。

\section{3. 切削に関与する土の性質 (土と金属との対比)}

土の切削実験により，切削による土の変形・土の内部 の応力分布・排土板にかかる応才の分布 ·切削抵抗など 
が明らかになった。これらの諸現象をひきおこす土の性 質としては，土の一般的な性質の他に, 特に切削で重要 なものとして，土の動的性質および土と平板との摩擦の 性質などがある。そこで本章ではこれらの問題を取り上 ゲ，実験結果の主なものを示し，金属との対応を調べて みる。

\section{（1）応力・ひずみの関係および破壊条件の 静水圧依存性}

ロームの応力・ひずみの関係を図 10 に示す、ひずみ $\varepsilon$ が増大すると応力 $\sigma$ も増大し, ある程度の $\varepsilon$ になると $\sigma$ は飽和する. 静水压 $\sigma_{w}$ を变光たとき， $\varepsilon-\sigma$ 曲線の形 はほとんど変化しない，また，口一ムの破壊条件は $\tau=$ $c+\sigma \tan \phi(\phi$ は小さい)で表わされる(図 11).

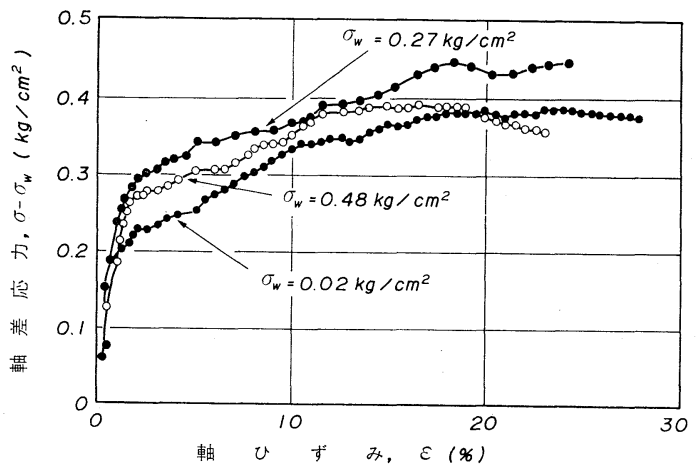

図 10 軟かいロームの応力ーひずみの関係.

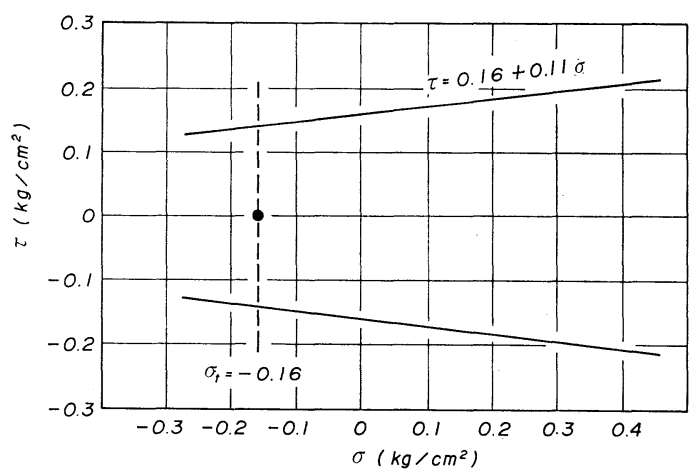

図 11 軟かいロームのせん断破壊条件.

ロ一ムの場合， $\sigma$ は $\varepsilon=20 \%$ 程度で飽和するが，金属 では20 80\%で飽和する。口一ムと金属(常温)との応 力の比は $10^{-4}$ 程度である。なお， $\varepsilon \cdot \sigma$ の履歴曲線も，両 者ともほとんど同じ形をしている。ロームの破壊条件は 静水压によってほとんど変化しない( $\phi$ が小さいので) が，金属の場合にも降伏条件は静水圧に依存しないけこ とはよく知られているところである。

$†$ アルミニウム・銅・鋼など, $f c c$ および $b c c$ 結晶 構造の材料の場合には本文の記述のと㧍りである が，チタン・ジルコニウムなぞ $h c p$ 結晶構造の 材料の場合には, 降伏条件は静水压汇依存し, 静 水圧の増加とともに降伏応力は大きくなる。

\section{（2）静水圧および軸圧による体積変化}

静水圧を加えたときのロームの体積変化を図 12 に， 軸圧を加光たときのそれを図13亿示す。静水圧 $\sigma_{w}$ を 増すと口ームの体積ひずみ $\varepsilon_{v}$ (圧縮 $:$ 正) は，はじめ急激 に增大し以後も $\sigma_{w}$ の增加とともに $\varepsilon_{v}$ は增大しつづけ る。一方，軸圧を加えたとき $\varepsilon_{v}$ ははじめゆるか增大 するが，軸压が增すに従って次第に $\varepsilon_{v}$ の増大が激しく なる。

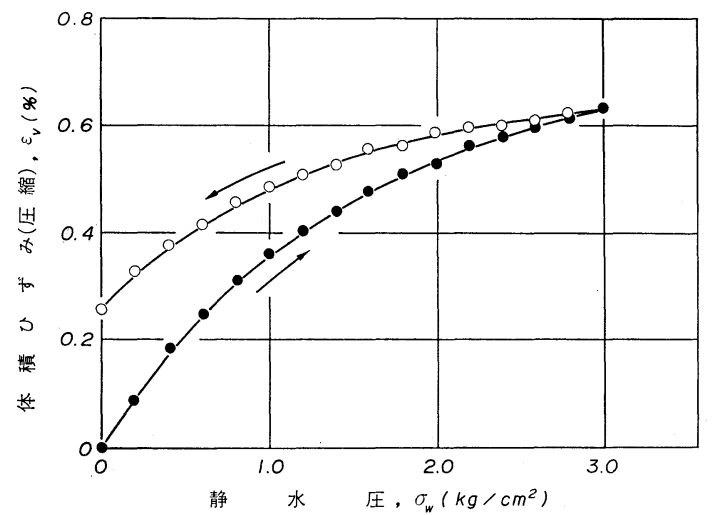

図 12 軟かいロームの静水圧による体積变化。

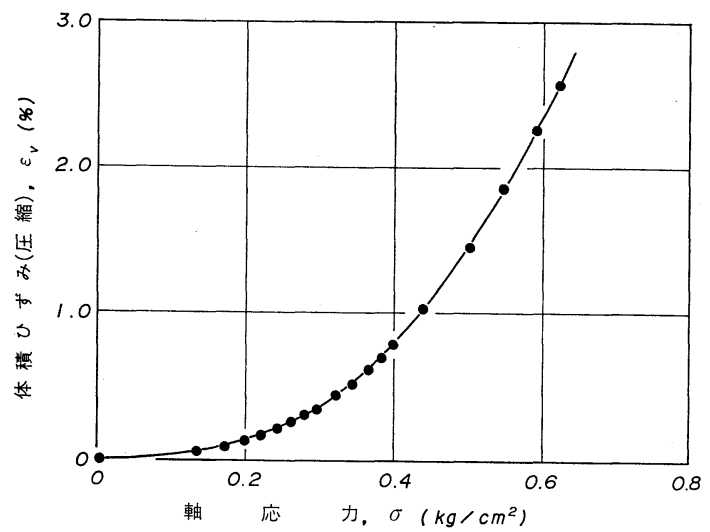

図 13 軟かいロームの軸応力による体積変化.

ロームの静水圧による体積変化は， $\sigma_{w}=2 \mathrm{~kg} / \mathrm{cm}^{2}$ の ときに約 $0.5 \%$ 程度である。一方，金属の静水圧による 体積变化は，だいたい $10^{-6} \sigma_{w}\left(\sigma_{w}: \mathrm{kg} / \mathrm{cm}^{2}\right)$ 程度である といわれている。ロームと金属との応力の比を $10^{4}$ 倍と してみると，静水圧による体積变化率は両者ともほ核同 程度の大きさになる。ロームの軸圧による体積変化は， 軸応力が $0.5 \mathrm{~kg} / \mathrm{cm}^{2}$ (ひずみは $30 \%$ 以上)のところで約 $1.5 \%$ 程度を示すが，金属では塑性変形がかなり進んで も体積変化は $0.05 \%$ 以下であるといわれている。この 点はロームと金属とが相違している点である。 


\section{（3）その他の塑性学的性質}

ロームの応力緩和・クリープ・時効硬化(練り返して からの時間による強度増加)等を図 14〜16に示す.

ロームのこれらの性質は, いずれも金属と似た傾向を 持っているが，時間スケールがかなり異っている。

\section{（4）土の動的性質}

ひずみ速度をパラメータとするロームの応力・ひずみ の関係を図 17 に示す。ひずみ速度を一定に保ってひず みを増加させたとき，応力は飽和曲線の形を呈するが， ひずみ速度の大きさによって飽和值が変化する。一般に 応力はひずみとひずみ速度に依存し，ひずみの大きい 程，またひずみ速度の大きい程大きくなる. 図 17 の $\varepsilon=$

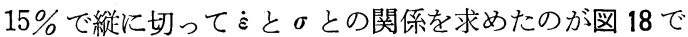
ある。これらの図から，応力 $\sigma\left(\mathrm{kg} / \mathrm{cm}^{2}\right)$,ひずみ $\varepsilon, ひ$

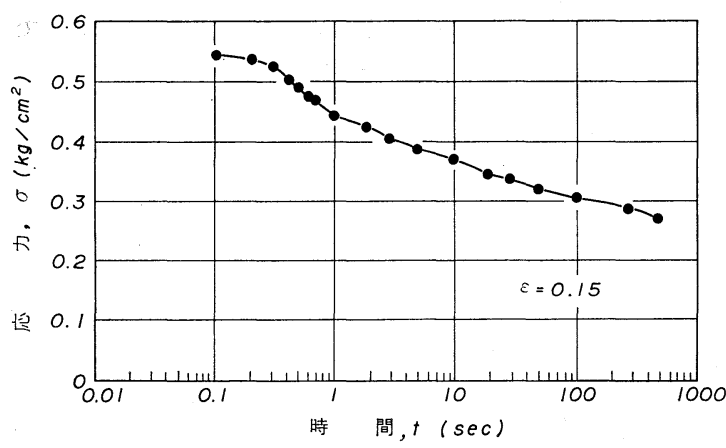

図 14 軟かいロームの応力緩和.

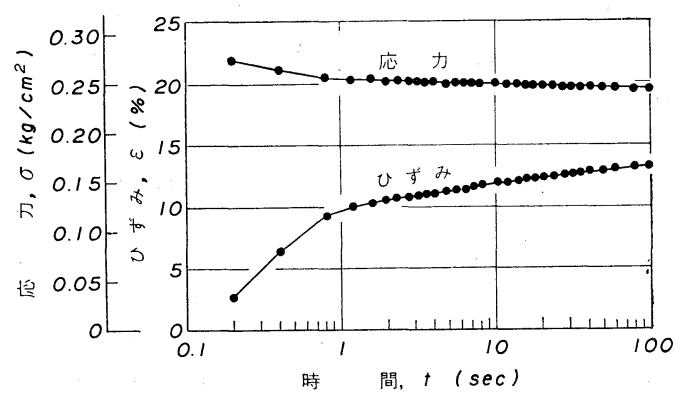

図15 軟かいロームのクリープ.

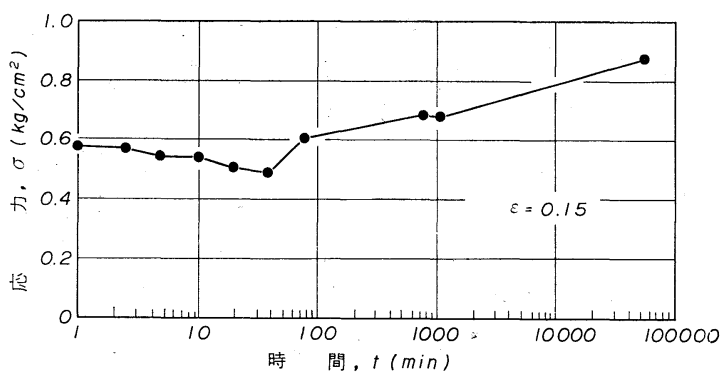

図 16 軟かいロームの時効硬化.

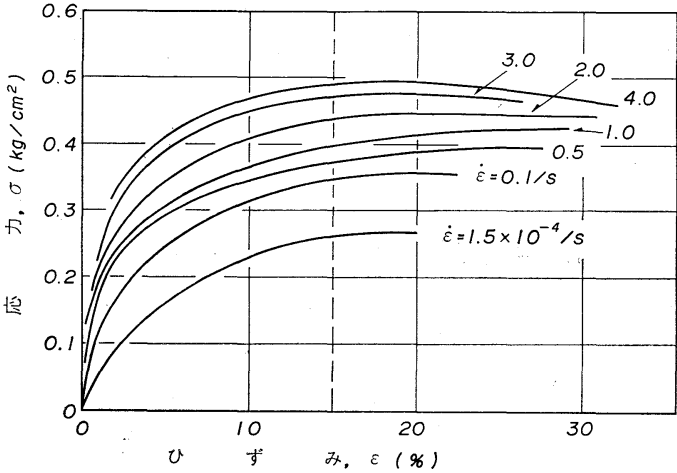

図 17 軟かいロームのひずみ速度による応力ーひずみ 曲線の変化.

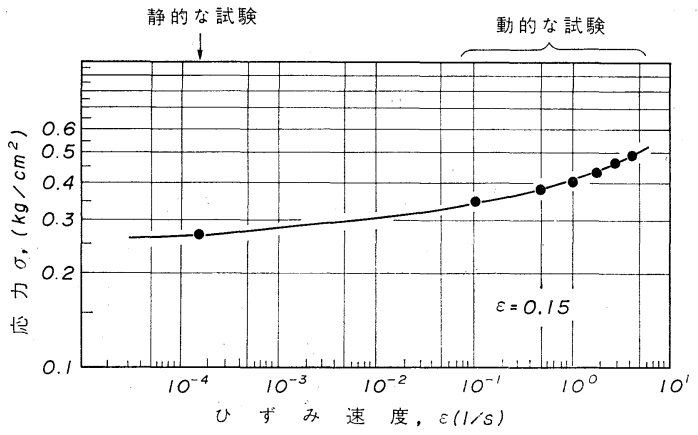

図 18 軟かいロームのひずみが一定の場合の応 カとひずみ速度の関係.

ずみ速度 $\dot{\varepsilon}(1 / \mathrm{sec})$ の間には, $\varepsilon=0.01 \sim 0.2, \dot{\varepsilon}=10^{-1} \sim 10 /$ $\sec$ の範囲では,

$$
\sigma=0.192 \log \left(\frac{\varepsilon}{0.15}\right)+0.42(\dot{\varepsilon})^{0.089}
$$

の関係がある.

金属の場合にも，ひずみ速度を大きくすると降伏応 力，塑性流動応力などが増加することが知られて括り， ひずみ速度 $\dot{\varepsilon}$ 応力 $\sigma$ との関係は，口ームのそれと同 様の形をしている(6).たと艺ば，ロームでは $\varepsilon=15 \%$ の とき实が $1 \rightarrow 10 / \mathrm{sec}$ に変わると応力は 1.5 倍になるが, 軟鋼 $\left(1200^{\circ} \mathrm{C}\right)$ でも $\dot{\varepsilon}$ が $10 \rightarrow 100 / \mathrm{sec}$ に変わると応力は 1.5 倍になるといわれている。

ところで金属の切削では, 温度を一定に保って切削し たときのせん断面上の平均せん断応力の值は，静的に求 めた降伏せん断応力よりはるかに大きいことが知られて いる，このことは，ロームの切削と全く同様である。と ころが通常の金属の切削では，一般に切削速度を増加さ せると切削抵抗の大きさは不変ないしは多少減少するこ とが知られている，この原因は，金属の切削では切削速 度を増すと温度が上昇してしまい，そのための強度減少 の方がひずみ速度増加による強度の増大よりも激しいた めであると考えられる。このように，土の切削のときに 
は問題とならない被削材の温度上昇が金属では問題とな る点が，ロームと金属との異なる点である.

(5) 土と平板との摩擦

ロームと平板との摩擦実験の結果を図 19 亿示す. 口-ムと平板との間の摩擦では, 圧力 $p$ 之摩擦応力 $f$ 之 の間には, $f=k+\mu p(k:$ ロームの種類・含水比拈よび平 板の種類や粗さなどによって定まる定数， $\mu$ : ほぼ口一 么の種類・含水比できまり平板の種類や粗さであまり変 らない定数)の関係がある。またロームの切削実験の結 果でも, 刃物と切屃との摩擦については, 摩擦応力が汪 ぼ一定になっている。

金属の切削では，すくい面の圧力の高いところでは摩 擦灾力が一定, 圧力の低いところでは摩擦俰数が一定に なっているといわれている，従ってロームと平板との摩 擦は金属の高圧での摩擦に対応しているものと考えられ る.

なお，口ームと平板との摩擦条件 $f=k+\mu p$ はローム の破壊条件 $\tau=c+\sigma \tan \phi$ と同じ形になっている。ロー ムと平板との摩擦に, 真の接触面積と見かけの接触面積 との比の概念を入れると, この現象がうまく説明される （図 20）。たと党ば，この比を 0.5 とし，真の接触面では 土同士ですべっているものとして土の動的性質をる考兄 に入れると，土と平板との摩擦の実験結果は切削中の土 と刃物との摩擦状態とほぽ一致する，金属の刃物表面と

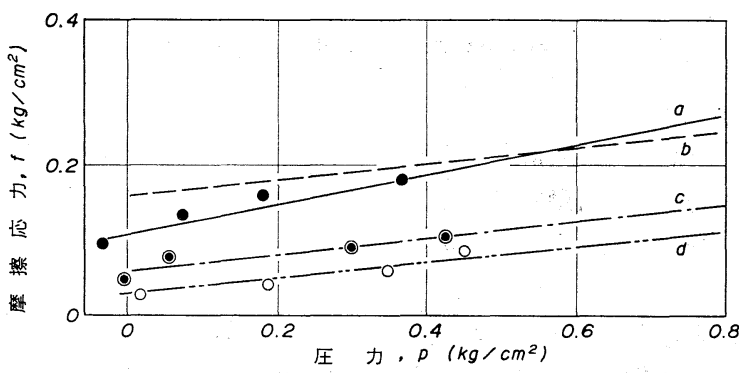

図 19 軟かいロームと平板との摩擦。 $a:$ 粗い鋼板 $f=0.11+0.20 \mathrm{p}$

$\mathrm{b}$ : ロームのせん断破壊条件 $\tau=0.16+0.11 \sigma$ c : 滑らかな鋼板 $f=0.06+0.11 \mathrm{p}$

$\mathrm{d}:$ : アリル板 $f=0.03+0.11 \mathrm{p}$

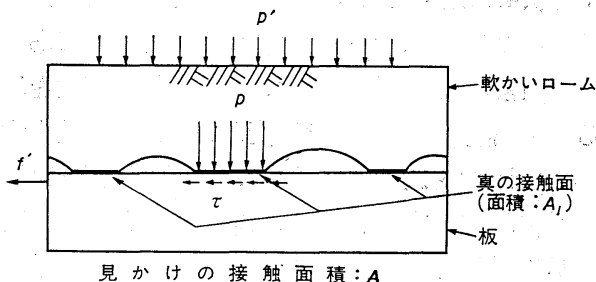

困 20 軟かいロームと板との接触状態.
切佰との摩擦でも同様の考学が行われ，現象をよく説明 するといわれている。

\section{（6）土の構造とその力学的性質}

ロームの力学的性質は，ロームが土粒子・水・空気の 三つから成立っていることで説明される(図 21).土の応 カ・ひずみの関係で,ひずみが増すと応力が増すのは主に 土粒子のために生じる。しかしせん断破壊応力が静水圧 によってほとんど変化しない点は，粒子をむすびっけて いるのが主に水の表面張力であるためであろう．静水圧 および軸圧によって体積が収縮するのは，土粒子の間隙 にある空気が圧縮されるためである。しかし，静水圧ま たは軸圧などを水だけで受け持っている訳ではなく，土 粒子の組織も多くの応力を受け持っている．応力がひず み速度に依存すること・応力緩和・クリープなどの主な 原因は，水が土粒子を結びつけているためであり，その 粘性により，土粒子の間隙を移動するのに圧力が必要で あったり時間がかかったりする，それらが前記の諸現象 として現われる。

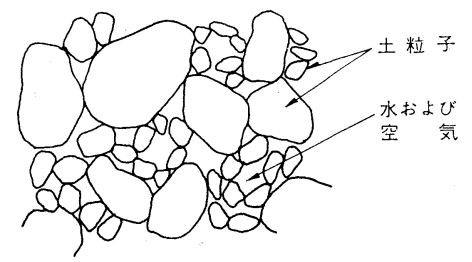

図 21 土の構造。

なお，プラスチシンもロームと同様の性質を持ってい るが，その原因は上述の水の役割を油が行っているため であると考えられる。

4. 土による金属のシミュレーション

2,3 章により，土の切削が金属のそれとよく似ている こと，その原因は両者の力学的性質がその構成要素等の 差にもかかわらずよく似ているためである等が明らかに なった，この相似性を逆に利用して，土を金属の力学的 シミュレーターとして用いる場合について考えてみよ 5.

金属の塑性加工のシミュレーターとしてプラスチシン （油粘土）が広く用いられているが，その力学的な性質を 調べてみると，常温 $\left(20^{\circ} \mathrm{C}\right.$ 前後)では， 3 章に述べた軟 かいロームとほとんど同じである。すなわち，応力・ひ ずみの関係性図 10 と注とんど同じである。降伏条件(ま たは破壊条件)の静水圧依存性は，口ーム上り小さく $\phi \fallingdotseq 1^{\circ}(\tan \phi \fallingdotseq 0.02)$ 程度である. 静水圧拉よび軸圧によ る体積变化も図 12,13 と汇とん゙゙同じである.応力緩 和はローム(因14)上り多少激しい。クリープは図 15 と 
同程度である，時効硬化(練り返してからの時間による 強度増加) は，ロームのそれと多少異った傾向を示し， 図22のようになる。動的性質については図 17, 18 とほ とんど同じである，平板との摩擦については実験を行っ ていないので確かなことはわからないが，処女面との摩 擦の場合には図 19 と同様に $f=k+\mu p$ の関係になって いるものと予想される。プラスチシンがロームと大きく 異なる唯一の点は, ロームでは温度の影響が実用上問題 とならないのに対し，プラスチシンの力学的性質は温度 に極めて敏感なことである．プラスチシンの降伏応力の 温度依存性を図 23 に示寸。

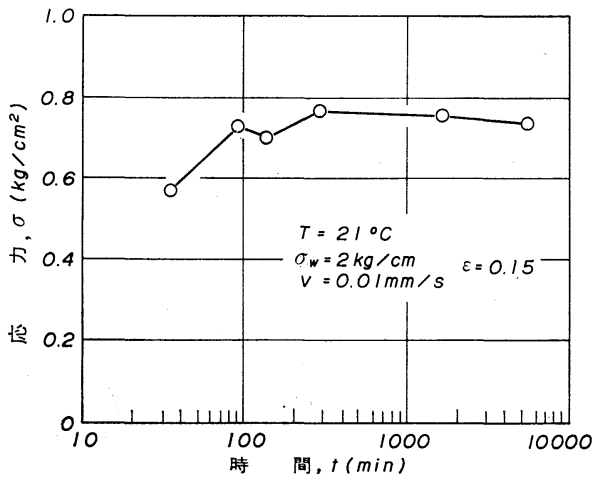

図 22 プラスチシンの時効硬化

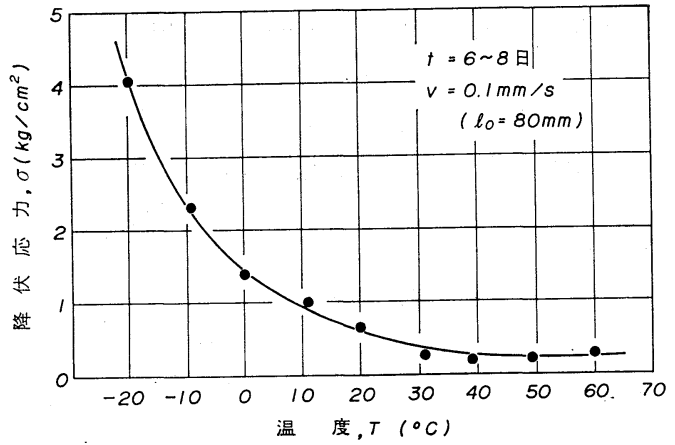

図 23 プラスチシンの降伏応力の温度依存性.

次に，プラスチシンを金属加工の力学的シミュレータ として用いる場合の具体的な問題点をいくつか挙げてみ よ5.

\section{（1）温度の影響}

図23からもわかるとおり，プラスチシンの応力は温 度に対し極めて敏感である。たとえば $20^{\circ} \mathrm{C} て ゙ ~ 10^{\circ} \mathrm{C}$ 程 度の温度変動があると，その降伏応力はひどいときには 60\% 程度の変化をしてしまう。このため, 実験に際し てプラスチシンの温度を一定に保つ必要がある他に，そ れぞれの力学的性質の測定に際しても実験と同一の温度 で行う必要がある。なお,プラスチシンの強度の温度依
存性の大きいことを逆に利用して, 種々の内部温度にな っている金属をシミュレートする方法も考えられる。た とえば, 金属切削のシミュレータとして用いるなら, 被 削材中の温度は場所によって大きく異なり，そのための 強度の違いも大きいと考えられるので, プラスチシンの 内部温度をそれに応じて変えてやるといった工夫が必要 となろら。

\section{(2) 時効硬化}

図 22 に示したように,プラスチシンの強度が安定す るには練り返して試料を作成してから, 約 2 時間の時間 を要する，従って実験に際しては，この条件を満すよう にしないと何を測っているのかわからなくなる。

\section{（3）動的性質}

プラスチシンの応力はひずみ速度によって大きく変化 する. 加工実験中のプラスチシンのひずみ速度が $1 / \mathrm{sec}$ 程度の大きさになると，同一のひずみに対しても，ひず み速度の増加 10 倍当り応力が 1.5 倍になるので，実際 に加工中の金属のひずみ速度による応力变化と等価な応 力増加を起させるように，モデル実験を計画する必要が ある。

また, プラスチシン・金属ともに，応力・ひずみの関 係を静的 $\left(\dot{\varepsilon}=10^{-4} \sim 10^{-3} / \mathrm{sec}\right.$ のオーダー)で測っておく 他に，ひずみ速度の影響を予め測っておくことが重要で ある。

\section{(4) 摩擦}

プラスチシンと平板との摩擦は，図 19 と同様の傾向 $(f=k+\mu p$ で $\mu$ は小さい,いいかえると摩擦応力がほぼ 一定)を持つもの予想されるが,圧延材とロール表面, 押 出し材とュンテナなどの間の摩擦などのように摩擦係数 一定の場合には，プラスチシン表面とモデルのロール， コンテナなどとの間で摩擦係数も一定にする工夫が必要 になる。

\section{（5）測 定}

プラスチシンと加工具との境界面の応力（圧力と摩擦 応力)の測定には図 4,6 の小形王力計と摩擦力計を, プ ラスチシン内部の応力測定には図 7 の小形土中セルなど を利用することができる．しかしこれらの検出器は市販 されていないので，読者自身で製作できさえすれば，種 々の加工法の力学的シミュレーションが可能になる(7).

\section{5. ま め}

以上，土の切削を中心に，土と金属との対比を行って きた．土と金属では，3章(6)にも述べたと拈り，その 構成要素(前者では土粒子・水・空気, 後者では金属原 子)拉よび構造(前者ではランダムな配置・蜂巣構造, 後 
者では結晶構造と結晶粒の配置)が全く異っているにも 拘らず，両者の切削に関与する力学的な性質がよく似て いることは大変興味深いことである。またこのことから 逆に，金属の力学的な性質を説明する学問(熱力学・転 位論など) と類似の学問が土について子必要になること が考えられる。

なお，本報は，東京大学工学部産業機械工学科千々岩 研究室で行っている一連の実験を基にまとめたものであ る. 詳しくは文献(1)〜 (5)を参照されたい，また，紙 面の都合で，土と対比する金属の性質およびプラスチシ ンの性質などの図を載せることができなかった.

\section{文献}

（1）畑村洋太郎，千々岩健児；機械学会講演論文集， $(1973 \cdot 10)$, p.18.

（2）畑村洋太郎, 千々岩健児; 機峨学会講演論文集, $(1974 \cdot 4)$, p.4.

（3）畑村洋太郎, 千々岩健児; 機械学会講演論文集, $(1974 \cdot 11)$, p.15.

（4）千々岩健児,畑村洋太郎; 機峨学会誌, 74(1971), 8.

（5）畑村洋太郎，千々岩健児；機械学会講演論文集に 投稿中。

（6）白井英治，白樫高洋，益子正己：精密機械，37 (1971), 268

（7）五弓勇雄, 木原諒二, 小豆島 明 : 塑性加工学会 春期講演会概要，(1974), p.173.

\section{一一分科会報告一}

\section{宿題テーマ研究会}

高融点金属材料開発の基礎的諸問題

(第I，第亚総合分科会，関東支部共催）

昭和 50 年秋期大会の宿題テーマシンポジウムに予定 されている上記の分野について，10月 17 日，金属材料 技術研究所に执いて研究会が行なわれた。

まず企画世話人から，高融点金属材料は未来材料とし て，各分野でそれらの開発を促進することが要望されて いるが，例えば原子炬材料一つを取り上げても，未解決 の問題が山積しており，今後は基礎部門研究者と応用開 発部門研究者の連携プレーなしには開発は困難な状勢に あることが述べられ，この会の意義が強調された。

以下当日行なわれた講演の概略を紹介する。

松本は，V, Mo および Ta を含む $\mathrm{Nb}$ 合金について 測定された水素固溶度の变化を, 水素添加によって引起 されるX線回折線の半価幅の減少と Nb-Mo-H 合金の 焼入時効過程での電気抵抗变化から, 置換型溶質原子と 水素との相互作用によって説明した。

花田は，V， Nb および Ta に含まれる水素と重水素の 低温に打汓る挙動を, 液体へリウム温度に焼入した後の 電気抵抗変化の湘定によって追跡し，それらの移動度の 温度依存性を求めて, 理論の妥当性について論じた。

奥田は，高融点体心立方金属の低温照射後の点欠陥回 復過程を, 主として電気抵抗と内耗測定によって調べ, $\mathrm{W}, \mathrm{Ta}, \mathrm{Mo}$ のような高融点金属でも $15,17,28^{\circ} \mathrm{K}$ とい ら極低温において格子間原子の移動による回復ステージ が見出されることを述べ，その回復機構につき論じた。

石野は, 内耗拈よび電気抵抗測定によってV中の酸素 の挙動について多面的な研究を紹介した。まず Snoek Peak Height と残留抵抗への酸素の寄与について述べた
後, 酸素と格子欠陥および置換型不純物との相互作用に 関して報告した:

諸住はV-Zr および V-Si 合金の内部酸化による高温 強度の向上におよぼす諸因子について検討した。その結 果 $\mathrm{V}-0.32 \mathrm{Zr}$ 合金では， $1000^{\circ} \mathrm{C} ， 2$ 時間内部酸化した 場合, $20^{\circ} \mathrm{C}$ で $50 \mathrm{~kg} / \mathrm{mm}^{2}, 800^{\circ} \mathrm{C}$ で $35 \mathrm{~kg} / \mathrm{mm}^{2}$ の強度 を示すことを報告し，さらに再結晶温度との関連，その 強化機構などについても述べた。

大庭は，純 W, Mo, Ta の再結晶の基本的機構につい て述べ，核形成過程に打ける圧延マトリクスと微細組織 との coincidence relation と plane matching による境 界エネルギー低下の重要性を強調した。

岡田は，Nb, Mo 合金の耐酸化性被覆の基本的プロセ スと実験例を報告した、V 合金にCVD 法によって Mo を被覆した場合，液体ナトリウム中での高温腐食実験に おいて好結果を得た。

松本は，Mo 合金の溶接性とへリウム，水素ガス中で 加熱した場合の脆性の問題を中心として, 開発研究途上 において見出された興味ある現象を加えながら報告し た.

最後に，木村から，仙台で行なわれる予定の第 2 回研 究会の説明があった後, この研究会のようにテーマの範 囲が非常に広い場合は，お互いに共通の関心をもてる問 題をもつことは容易ではないが，例总ば松本氏が報告し たような，Mo 合金鋳塊を溶接した場合，再結晶粒界脆 性のようなタイプの粒界割れは起らないといらような基 礎研究者にも興味ある問題が数多く提出されるようにな れば, 研究会の意義は一層増すという趣旨のしめくくり があった。

企画世話人の反省としては，講演時間が大幅に超過 し，1日に 9 テーマの消化は無理であったこと，また討 論の形式にもさらに工夫する必要を感じた。

（企画世話人 大庭幸夫） 